\title{
Stuffing Carbon Away: Mechanisms of Carbon Sequestration in Soils
}

P. J. Reimer, C. A. Masiello, J. R. Southon, S. E. Trumbore, J. W. Harden, A. F. White, O. A. Chadwick, M. S. Torn

\section{January 24, 2003}

Lawrence

Livermore

National

Laboratory

U.S. Department of Energy

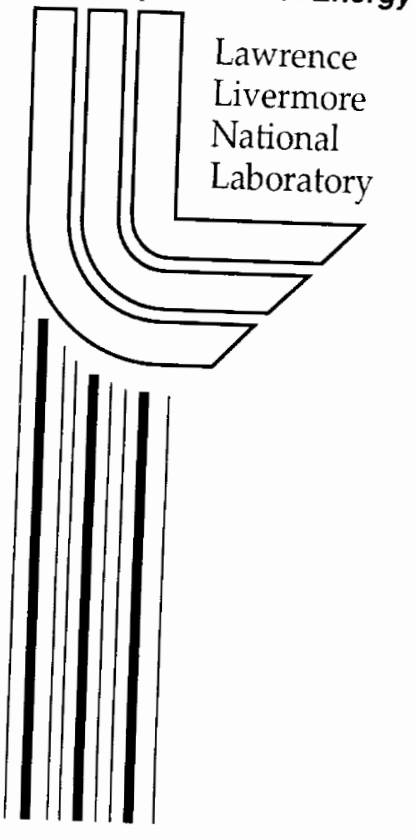





\section{DISCLAIMER}

This document was prepared as an account of work sponsored by an agency of the United States Government. Neither the United States Government nor the University of California nor any of their employees, makes any warranty, express or implied, or assumes any legal liability or responsibility for the accuracy, completeness, or usefulness of any information, apparatus, product, or process disclosed, or represents that its use would not infringe privately owned rights. Reference herein to any specific commercial product, process, or service by trade name, trademark, manufacturer, or otherwise, does not necessarily constitute or imply its endorsement, recommendation, or favoring by the United States Government or the University of California. The views and opinions of authors expressed herein do not necessarily state or reflect those of the United States Government or the University of California, and shall not be used for advertising or product endorsement purposes.

This work was performed under the auspices of the U. S. Department of Energy by the University of California, Lawrence Livermore National Laboratory under Contract No. W-7405-Eng-48.

This report has been reproduced directly from the best available copy.

Available electronically at http://www.doc.gov/bridge

Available for a processing fee to U.S. Department of Energy

And its contractors in paper from

U.S. Department of Energy

Office of Scientific and Technical Information

P.O. Box 62

Oak Ridge, TN 37831-0062

Telephone: (865) 576-8401

Facsimile: (865) 576-5728

E-mail: reports@adonis.osti.gov

Available for the sale to the public from

U.S. Department of Commerce

National Technical Information Service

5285 Port Royal Road

Springfield, VA 22161

Telephone: (800) 553-6847

Facsimile: (703) 605-6900

E-mail: orders@ntis.fedworld.gov

Online ordering: http://www.ntis.gov/ordering.htm

OR

Lawrence Livermore National Laboratory

Technical Information Department's Digital Library

http://www.llnl.gov/tid/Library.html 

Stuffing Carbon Away: Mechanisms of Carbon Sequestration in Soils

00-ERI-010 Final Report

P.J. Reimer ${ }^{1}$, C.A. Masiello ${ }^{2}$, J.R. Southon ${ }^{3}$, S.E. Trumbore ${ }^{3}$, J.W. Harden ${ }^{4}$, A.F. White, O. A. Chadwick, and M.S. Torn ${ }^{6}$

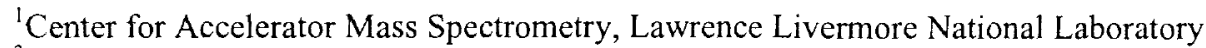

${ }^{2}$ Geological and Planetary Sciences, California Institute of Technology

${ }^{3}$ Department of Earth System Science, University of California - Irvine

${ }^{4}$ US Geological Survey, Menlo Park

${ }^{5}$ Geography \& Environmental Studies Program, University of California -- Santa Barbara

${ }^{6}$ Earth Sciences, Lawrence Berkeley National Laboratory

This work was performed under the auspices of the U. S. Department of Energy by the University of California, Lawrence Livermore National Laboratory under Contract No. W-7405-Eng-48.

\section{Project Overview}

Soils offer the potential to sequester large quantities of carbon from the atmosphere for decades to millennia and so may ameliorate the anthropogenic influence of fossil fuel release. However changes in climate can drastically affect the soil s ability to store carbon through changes mineralogy on time scales of human interest. It is essential to understand the major controls on soil carbon dynamics before we attempt to manage sequestration to control atmospheric $\mathrm{CO}_{2}$ buildup.

Models of the terrestrial carbon cycle often use clay content to parameterize soil carbon turnover. Evidence from volcanic soils suggests that soil mineralogy is a major control on a soil s ability to store carbon, because different types of minerals have widely varying abilities to physically and chemically isolate soil organic matter from decomposition, however volcanic soils represent only a small percentage of the earth $\mathrm{s}$ soils. The relationship between precipitation and soil carbon storage is also complex and poorly constrained. Significantly, precipitation changes predicted as a result of atmospheric $\mathrm{CO}_{2}$ doubling include increased rainfall throughout California. We utilized ${ }^{14} \mathrm{C}, \delta^{13} \mathrm{C}$, and the total organic carbon, iron, and aluminum contents to address the question of the importance of mineralogy and climate on carbon storage in soils formed on a globally representative parent material.

The California coastal terraces, formed over the last 500 thousand years as a result of tectonic uplift and sea level change, provide a natural laboratory to examine the effect of mineralogy and climate on carbon storage. We have focused on two terraces sequences, one near Eureka and one near Santa Cruz. Within each set of terraces only soil mineral development varies; all other variables are constant (rainfall, plant systems, and soil parent material, and land management). Annual precipitation at Eureka is twice that at Santa Cruz, allowing us to examine its role in the transport of organic carbon to deeper horizons. The objective of the study is to improve the understanding of soil carbon storage and derive a set of proxies for organic carbon turnover for terrestrial carbon cycle models. 
Stuffing Carbon Away: Mechanisms of Carbon Sequestration in Soils

00-ERI-010 Final Report

P.J. Reimer ${ }^{1}$, C.A. Masiello ${ }^{2}$, J.R. Southon ${ }^{3}$, S.E. Trombore ${ }^{3}$, J.W. Harden ${ }^{4}$, A.F. White ${ }^{4}$, O. A. Chadwick ${ }^{5}$, and M.S. Torn ${ }^{6}$

${ }^{1}$ Center for Accelerator Mass Spectrometry, Lawrence Livermore National Laboratory

${ }^{2}$ Geological and Planetary Sciences, California Institute of Technology

${ }^{3}$ Department of Earth System Science, University of California - Irvine

${ }^{4}$ US Geological Survey, Menlo Park

${ }^{5}$ Geography \& Environmental Studies Program, University of California - Santa Barbara

${ }^{6}$ Earth Sciences, Lawrence Berkeley National Laboratory

This work was performed under the auspices of the U. S. Department of Energy by the University of California, Lawrence Livermore National Laboratory under Contract No. W-7405-Eng-48.

\section{Project Overview}

Soils offer the potential to sequester large quantities of carbon from the atmosphere for decades to millennia and so may ameliorate the anthropogenic influence of fossil fuel release. However changes in climate can drastically affect the soil's ability to store carbon through changes mineralogy on time scales of human interest. It is essential to understand the major controls on soil carbon dynamics before we attempt to manage sequestration to control atmospheric $\mathrm{CO}_{2}$ buildup.

Models of the terrestrial carbon cycle often use clay content to parameterize soil carbon turnover. Evidence from volcanic soils suggests that soil mineralogy is a major control on a soil's ability to store carbon, because different types of minerals have widely varying abilities to physically and chemically isolate soil organic matter from decomposition, however volcanic soils represent only a small percentage of the earth's soils. The relationship between precipitation and soil carbon storage is also complex and poorly constrained. Significantly, precipitation changes predicted as a result of atmospheric $\mathrm{CO}_{2}$ doubling include increased rainfall throughout California. We utilized ${ }^{14} \mathrm{C}, \delta^{13} \mathrm{C}$, and the total organic carbon, iron, and aluminum contents to address the question of the importance of mineralogy and climate on carbon storage in soils formed on a globally representative parent material.

The California coastal terraces, formed over the last 500 thousand years as a result of tectonic uplift and sea level change, provide a natural laboratory to examine the effect of mineralogy and climate on carbon storage. We have focused on two terraces sequences, one near Eureka and one near Santa Cruz. Within each set of terraces only soil mineral development varies; all other variables are constant (rainfall, plant systems, and soil parent material, and land management). Annual precipitation at Eureka is twice that at Santa Cruz, allowing us to examine its role in the transport of organic carbon to deeper horizons. The objective of the study is to improve the understanding of soil carbon storage and derive a set of proxies for organic carbon turnover for terrestrial carbon cycle models. 
Activities and analytical results

Soil samples were collected from each soil horizon down to bedrock for each terrace. ${ }^{14} \mathrm{C}, \delta^{13} \mathrm{C}$, and mineral content were measured on all the samples. We examined the relationship between the concentrations of two types of metastable intermediates and the capacity of soils to hold organic matter (measured by soil carbon concentration and radiocarbon age.) As a control, we compared the correlation between organic carbon storage and metastable weathering product content with the correlation between organic carbon storage and clay content. We found that organo-metal complexes were highly correlated with organic carbon storage, while amorphous mineral content and clay content were not significantly correlated. Clay content (grain size) is commonly used as a proxy for carbon turnover times in carbon cycle models. Our results show that this parameterization is a poor predictor of carbon turnover. Soil carbon inventories integrated over the top meter peaked and weighted ${ }^{14} \mathrm{C}$ inventories reach a minimum in the intermediate-aged terraces where non-crystalline $\mathrm{Fe}$ and $\mathrm{Al}$ minerals were highest. There was a net decrease of soil carbon storage in the older profiles which suggests that the carbon sequestration potential of these soils drops as the mineralogy changes to higher clay content and more crystalline forms of $\mathrm{Fe}$ and $\mathrm{Al}$. The $\delta^{13} \mathrm{C}$ of the soil also peaked in the intermediate-aged terraces, which indicates there is either preferential storage of specific compound classes such as carbohydrates or lipids or fractionation of carbon compounds during microbial respiration. Preliminary ${ }^{13} \mathrm{C}-\mathrm{NMR}$ results show a higher concentration of unsaturated alkyl compounds, such as lipids and long chain fatty acids, in the oldest terrace at Eureka compared to one of the youngest terraces. A comparison between the Eureka and Santa Cruz sites showed that the higher precipitation at Eureka resulted in a larger soil carbon sink, directly, through increased soil development (weathering), and indirectly, through increased ecosystem primary productivity as indicated by deeper organic soil horizons with a slower carbon turnover rate (lower fraction modern ${ }^{14} \mathrm{C}$ ) as shown in Figure 1.

In FY2002 we installed lysimeters to collect water for measurement of dissolved organic carbon (DOC) from three soil horizons (A, AB, and B) at three of the Santa Cruz terraces. DOC concentration was highest in the $\mathrm{AB}$ and $\mathrm{B}$ horizons and in the early spring. Together with USGS and University of California colleagues we plan to seek funding to expand the project to include ${ }^{14} \mathrm{C}$ measurements on the DOC, bacterial biomass, and light and heavy soil fractions, as well as continuing to explore the mineralcarbon relationship. Together with physical and climatic parameters, these measurements will provide both a better understanding of soil carbon storage processes and input for modeling efforts.

\footnotetext{
Abstracts:

P.J. Reimer, C.A. Masiello, J. W. Harden, J. Munster, S.P. Anderson, A.F. White, M. S. Schulz, 2002, An Integrated Approach to Understanding controls on Soil Carbon Sequestration. Ninth International Conference on Accelerator Mass Spectrometry (AMS9), Nagoya, Japan, 9/9 - 9/13. UCRL-MI-150577
} 
Figure 1. Horizon depth and weighted mean soil ${ }^{14} \mathrm{C}$ in fraction modern versus terrace age in thousands of years for the Eureka and Santa Cruz terraces A and AB horizons (solid and open circles; solid and open squares, respectively). 


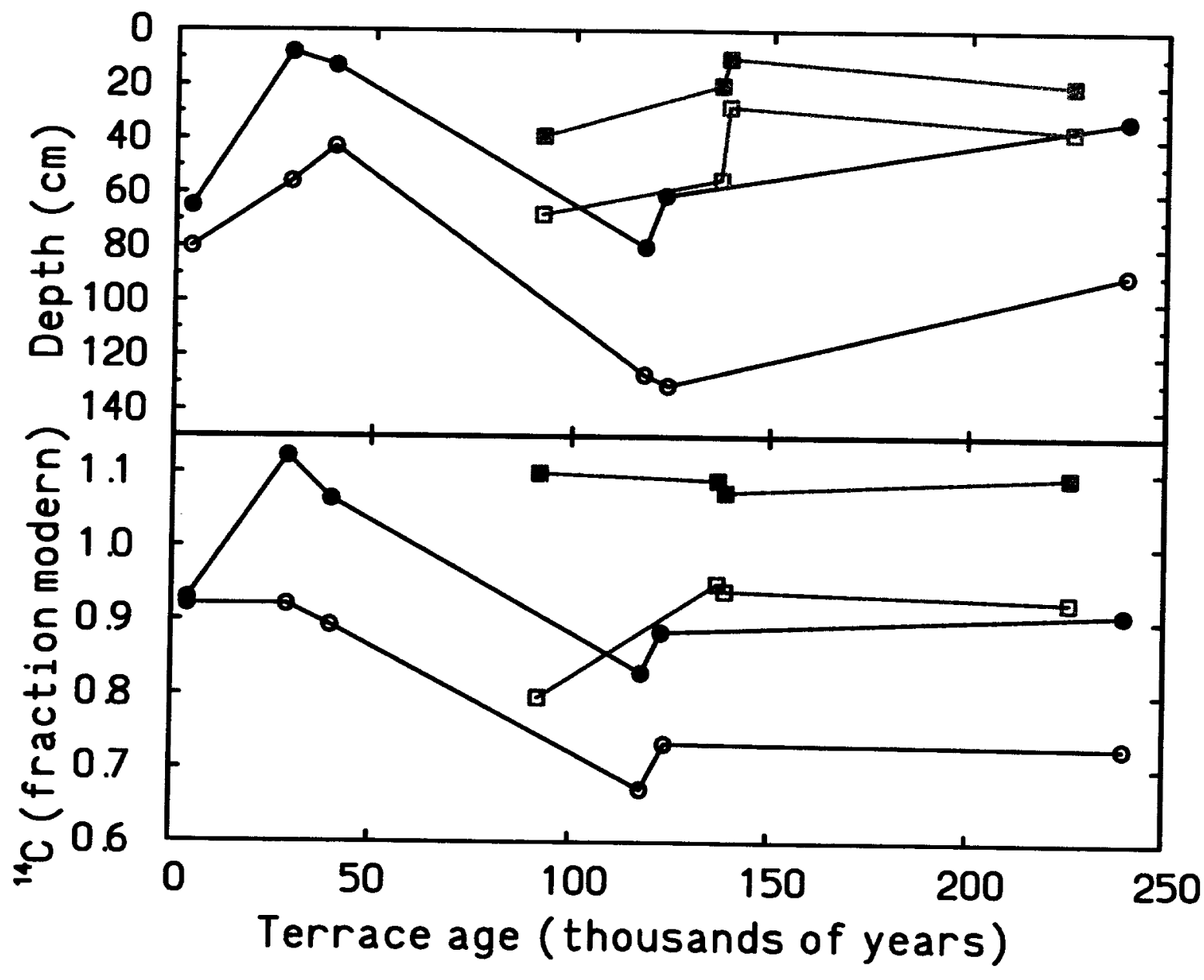


